\title{
Biodegradation and Micro- Scale Treatability Pattern of Loblolly Pine Heartwood Bioincised by Bacillus Subtilis and Physisporinus Vitreus
}

\section{Biorazgradnja i model impregnacije srži lobodijskog bora na mikrorazini, uz poboljšanje prodora zaštitnog sredstva primjenom Bacillus subtilis i Physisporinus vitreus}

\author{
Original scientific paper $\bullet$ Izvorni znanstveni rad \\ Received-prispjelo: 18. 8. 2020. \\ Accepted-prihvaćeno: 26. 5. 2021. \\ UDK: $630 * 841.51$ \\ https://doi.org/10.5552/drvind.2021.2034
}

\begin{abstract}
One strategy for improving the treatability of refractory wood species is biological incising, and its efficiency depends on how the microorganisms modify the porous structure of the wood. Evaluation of the bioincised wood treatability on a micro-scale can thus help to better understand the treatability enhancing mechanisms. In the present study, the biodegradation pattern and micro-scale treatability of Loblolly pine (Pinus taeda L.) heartwood were determined after bioincising with the white-rot fungus Physisporinus vitreus (Pers.: Fr.) P. Karsten isolate 136 and bacterium Bacillus subtilis UTB22. Oven-dried specimens with dimensions of $50 \mathrm{~mm} \times 25$ $m \mathrm{~mm} \times 15 \mathrm{~mm}(L \times T \times R)$ were incubated with the microorganisms at $(23 \pm 2){ }^{\circ} \mathrm{C}$ and $(65 \pm 5) \%$ relative humidity for six weeks. The control and exposed wood blocks were then pressure treated by $1 \%$ fluorescent dye (fluorescein)containing water to study the treatability pattern under a fluorescence microscope. The longitudinal and tangential air permeability and compression strength parallel to the grain of the specimens were also determined at the end of the incubation period. Scanning electron microscopic (SEM) studies showed that degradation by $\underline{B}$. subtilis UTB22 was limited to the pit membranes, but the cell walls were also degraded to some extent by $\underline{P}$. vitreus. The fungus caused a higher mass loss compared to the bacterium, whereas the permeability enhancing ability of the bacterium was more pronounced. The fluorescent dye tracer also showed that higher treatability with more uniformity was obtained by $\underline{B}$. subtilis $U T B 22$. The improvement in treatability by both microorganisms was mainly due to the degradation of the earlywood tracheids.
\end{abstract}

Keywords: Bacillus subtilis; bioincising; penetration; Physisporinus vitreus; wood treatability

\footnotetext{
${ }^{1}$ Authors are researchers at University of Tehran, Faculty of Natural Resources, Department of Wood and Paper Science and Technology, Karaj, Iran.

2 Author is researcher at University of Ljubljana, Biotechnical Faculty, Department of Wood Science and Technology, Ljubljana, Slovenia.

3 Author is researcher at University of Tehran, Department of Plant Protection, Karaj, Iran.
} 
SAŽETAK • Jedna od metoda poboljšanog impregniranja slabo poroznih vrsta drva jest tretiranje drva mikroorganizmima, a cilj tog postupka jest promjena porozne strukture drva. Evaluacija tretmana drva mikroorganizmima može pridonijeti boljem razumijevanju mehanizama poboljšanja prodora zaštitnog sredstva u drvo. U ovom je istraživanju promatrana biorazgradnja i impregnacija srži lobodijskog bora (Pinus taeda L.) na mikrorazini nakon izloženosti drva gljivi bijele truleži Physisporinus vitreus (Pers.: Fr.) P. Karsten izolat 136 i bakteriji Bacillus subtilis UTB22. Apsolutno suhi uzorci drva dimenzija $50 \mathrm{~mm} \times 25 \mathrm{~mm} \times 15 \mathrm{~mm}(L \times T \times R)$ zaraženi su mikroorganizmima pri $23 \pm 2{ }^{\circ} \mathrm{C}$ i $65 \pm 5 \%$ relativne vlažnosti zraka tijekom šest tjedana. Nakon toga kontrolni $i$ zaraženi blokovi drva tlačnim su postupkom impregnirani fluorescentnim bojilom otopljenim u vodi (1\%-tni fuorescein) kako bi se pod fuorescentnim mikroskopom promotrio učinak tretmana drva mikroorganizmima. Na kraju inkubacije utvrđena je propusnost zraka u uzdužnom i tangentnom smjeru te izmjerena čvrstoća na tlak paralelno $s$ vlakancima. Istraživanje pretražnim elektronskim mikroskopom (SEM) pokazalo je da je razgradnja bakterijom B. subtilis UTB22 ograničena na membrane jažica, dok su stanične stijenke u određenoj mjeri razgrađene djelovanjem gljive P. vitreus. Gljiva je uzrokovala opsežniji gubitak mase nego bakterija, dok je sposobnost bakterije da poveća propusnost bila veća. Fluorescentno bojilo također je pokazalo da je bakterijom B. subtilis UTB22 postignuta bolja propusnost, s većom ujednačenošću. Poboljšanje propusnosti primjenom obaju mikroorganizama uglavnom je posljedica razgradnje traheida ranog drva.

Ključne riječi: Bacillus subtilis; tretiranje drva mikroorganizmima; prodor Physisporinus vitreus; impregniranje drva

\section{INTRODUCTION 1. UVOD}

Most wood species are not sufficiently durable against wood-destroying organisms and have to be treated with chemical preservatives to ensure the desired service life or to improve other relevant properties like resistance to fire and UV stability. Preservatives Adequate penetration of the wood by the preservatives during the treatment process is necessary to achieve a successful protection against biological degradation. However, the penetration depth of active ingredients alone is not sufficient to judge the wood treatability; the uniformity of the penetration should be evaluated, e.g., by microscopic studies of the treated wood (Tarmian et al., 2020). Wood decay can occur from the non-uniform impregnation of the wood cells (Omidvar and Schneider, 2004). This type of penetration is sometimes called marble penetration.

Various strategies can be used to enhance the penetration of the preservatives into refractory wood species, among which mechanical incising is commonly used in industry for this purpose (Hansmann et al., 2002; Morrell and Morris, 2002; Lehringer et al., 2009 a, b; Evans 2016; Tarmian et al., 2020). Biological incising (i.e. bioincising) using a variety of fungi and bacteria can also be considered as a wood treatability enhancing method which might have the potential for industrial upscaling (Johnson, 1979; Daniel, 2003; Mai et al., 2004; Schwarze et al., 2006; Pánek and Reinpercht, 2008, 2011; Lehringer et al., 2011; Fuhr et al., 2011; Thaler et al., 2012; Yildiz et al., 2012; Dale et al., 2019). For example, it has been known for a long time that some bacteria (e.g., Bacillus subtilis) are able to increase the permeability of some refractory coniferous wood species during ponding or water sprinkling by deteriorating the bordered pit membranes (Pánek and Reinprecht, 2008; Yildiz et al., 2012).

The white-rot fungus Physisporinus vitreus has been used as a bioincising fungus to enhance the permeability of some refractory softwood species, like
Norway spruce (Picea abies), without any considerable reduction in the mechanical strength of the wood (Schmidt et al., 1997; Schwarze and Landmesser, 2000; Schwarze et al., 2006, 2008; Lehringer et al., 2010, 2011; Schwarze and Schubert, 2011; Emaminasab et al., 2015, 2016). It is claimed that $P$. vitreus is able to selectively degrade pectin-rich pit membranes under certain incubation conditions (Schmidt et al., 1997; Schwarze and Landmesser, 2000; Lehringer et al., 2010; Fuhr et al., 2011).

Some works have evaluated the treatability of wood after bioincising with Bacillus sp. (Pánek and Reinprecht, 2011; Yildiz et al., 2012) and P. vitreus (Schwarze et al., 2006; Volkmer et al., 2010; Lehringer et al., 2011; Emaminasab et al., 2015, 2016) with macro-scale analyses. The current study gives some detailed information on the micro-scale treatability of bioincised wood which could be helpful in achieving an in-depth understanding of the treatability-enhancing mechanisms.

\section{MATERIALS AND METHODS} 2. MATERIJALI I METODE

\subsection{Wood sample preparation}

\subsection{Priprema uzoraka drva}

Wood specimens with dimensions of $50 \mathrm{~mm} \times 25$ $\mathrm{mm} \times 15 \mathrm{~mm}(\mathrm{~L} \times \mathrm{T} \times \mathrm{R})$ were prepared from the heartwood of air-dried Loblolly pine (Pinus taeda L.) boards according to EN 113:2004 for fungal and bacterial incubation. Loblolly pine is native to the southeastern United States and widely grown on plantations as well. Wood samples from the trees planted in northern Iran were used for this study. The treatability class of Loblolly pine heartwood varies from III to IV, indicating that it is difficult or extremely difficult to treat (EN 350: 2016). Compression strength parallel to the grain of the specimens with dimensions of $60 \mathrm{~mm} \times 20 \mathrm{~mm}$ $\times 20 \mathrm{~mm}(\mathrm{~L} \times \mathrm{T} \times \mathrm{R})$ was also determined according to DIN 52185:1976. Five replicates were used for each test. 


\subsection{Incubation by $B$. subtilis and $P$. vitreus}

2.2. Inkubacija pri izloženosti drva $B$. subtilis i $P$. vitreus

The wood samples were oven dried at $(103 \pm 2){ }^{\circ} \mathrm{C}$ for $24 \mathrm{~h}$, steam-sterilized at $121^{\circ} \mathrm{C}$ and $124.1 \mathrm{kPa}$ for 20 min, and weighed before fungal and bacterial exposure. Physisporinus vitreus (Pers.: Fr.) P. Karsten isolate 136 was obtained from the University of Hamburg (Bari et al., 2015). The woodblocks were exposed to fungal mycelia grown in Kolle flasks containing 4.8 \% malt extract agar (Merck, Germany).

Bacillus subtilis UTB22 was obtained from the Department of Plant Protection at the University of Tehran. One ml of B. subtilis UTB22 was transferred to sterilized Luria Bertani aqua culture medium and put in a shaker incubator for $120 \mathrm{~min}^{-1}$ at $28{ }^{\circ} \mathrm{C}$ for 24 $\mathrm{h}$. The bacterium was harvested by centrifugation for 6 minutes at $8000 \mathrm{~min}^{-1}$. A suspension of bacterium and distilled water was supplied, and the optimum population of bacteria was determined using a spectrophotometer. Incubation by both microorganisms was carried out at a temperature of $(23 \pm 2){ }^{\circ} \mathrm{C}$ and $(65 \pm 5) \%$ relative humidity for 6 weeks. At the end of incubation, the samples were oven dried and weighed to calculate the mass loss. A Scanning Electron Microscope (SEM; Zeiss DSM 960 A, Germany) was used to observe the biodegradation pattern of the incubated specimens.

\subsection{Micro-scale treatability test}

\subsection{Ispitivanje impregnacije na mikrorazini}

The control and incubated wood specimens with a moisture content of $12 \%$ were pressure treated with $1 \%$ fluorescent dye (fluorescein)-containing water. Before the impregnation process, the end sections of the specimens were completely coated with epoxy resin to limit solution penetration through the transverse direction. An initial vacuum of $30 \mathrm{kPa}$ was first applied for 20 minutes, and then impregnation was carried out at atmospheric pressure for 30 minutes. Transverse sections of about 10-15 $\mu \mathrm{m}$ thickness were cut from the treated specimens using a sledge microtome (GSL1) and studied by fluorescence microscopy (BEL FLUO3 , Italy). Under the UV light of the microscope (exciting spectrum area: $330-400 \mathrm{~nm}$ ), the treated area gave off a green color.

\subsection{Measuring air permeability}

There is a strong correlation between wood treatability and air permeability (Siau, 1984). Thus, air permeability of the specimens was also measured. For this purpose, cylindrical samples $18 \mathrm{~mm}$ in diameter and 20 $\mathrm{mm}$ in length were cut along the longitudinal and tangential directions of the wood specimens with ten replicates for each treatment. The lateral surfaces of the specimens conditioned to equilibrium moisture content $(E M C)$ of about $12 \%$ were first coated by epoxy resin to avoid lateral air leakage. Superficial gas permeability) was then determined under steady-state conditions based on Darcy's law using a well-known falling-water displacement method suggested by Siau (1984) (see Figure 1 for details of the apparatus):

$$
k_{\mathrm{g}}=\frac{V_{\mathrm{d}} \cdot C \cdot L \cdot\left(P_{\mathrm{atm}}-0.074 \cdot \bar{h}\right)}{t \cdot A \cdot(0.074 \cdot \bar{h}) \cdot\left(P_{\mathrm{atm}}-0.037 \cdot \bar{h}\right)} \cdot \frac{0.760 \mathrm{mHg}}{1.013 \cdot 10^{5} \mathrm{~Pa}}(1)
$$

Where $V_{\mathrm{d}}=\pi \cdot r^{2} \cdot \Delta z\left(\mathrm{~m}^{3}\right), P_{\mathrm{atm}}$ is the atmospheric pressure $(\mathrm{mHg}), L$ is the sample length $(\mathrm{m}), \bar{h}$ is the average height of water over surface of reservoir during period of measurement (m), $A$ is the cross-sectional area of specimen $\left(\mathrm{m}^{2}\right), t$ is the time (s) required for the water drop through $\Delta h$ and $C$ is the correction factor for gas expansion:

$$
C=1+\frac{V_{r} \cdot(0.074 \cdot \Delta h)}{V_{\mathrm{d}} \cdot\left(P_{\mathrm{atm}}-0.074 \cdot \bar{h}\right)}
$$

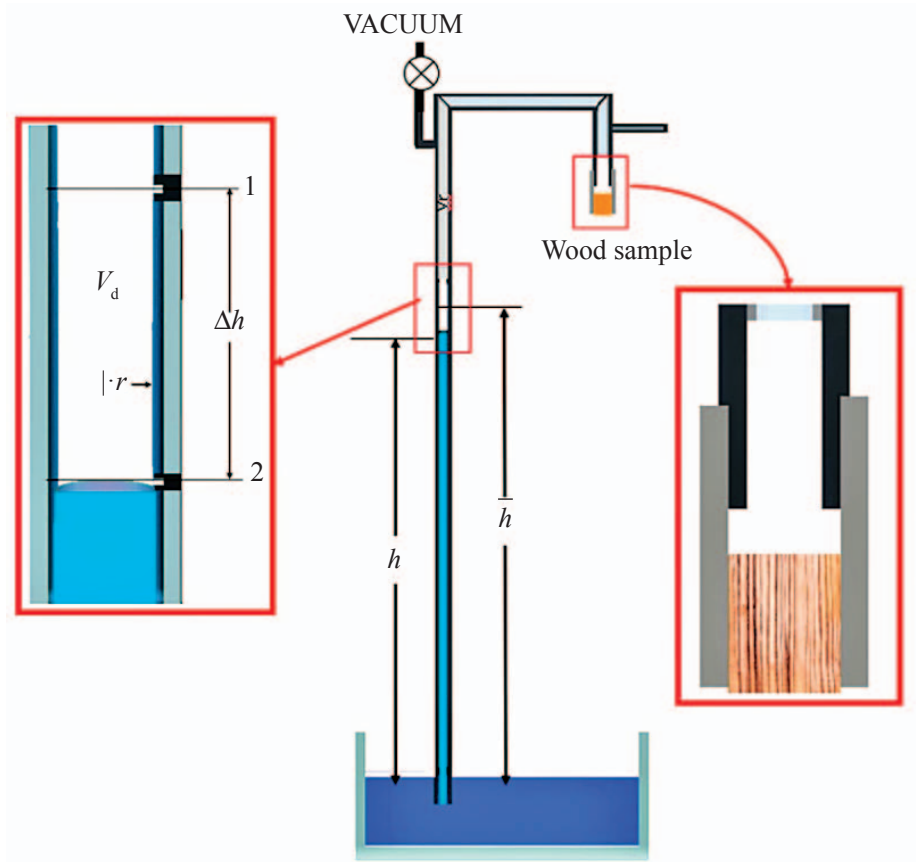

Figure 1 Schematic view of apparatus used to measure air permeability based on falling-water displacement method Slika 1. Shematski prikaz opreme za mjerenje propusnosti zraka koja se temelji na metodi istiskivanja vode 
Where $V$ is total volume of apparatus above point 1 including volume of hoses $\left(\mathrm{m}^{3}\right)$, and $\Delta h$ is change in the water drop level during the test $(\mathrm{m})$. Finally, the specific permeability coefficient $(K)\left(\mathrm{m}^{3} \mathrm{~m}^{-1}\right)$, which is only a function of the porous medium properties, was calculated by:

$$
K=k_{\mathrm{g}} \cdot \mu
$$

Where $\mu$ is the viscosity of air at $20{ }^{\circ} \mathrm{C}\left(\mu=1.81 \cdot 10^{-5}\right.$ $\mathrm{Pa} \cdot \mathrm{s})$.

\subsection{Statistical analysis}

2.5. Statistička analiza

Statistical analysis was conducted using SPSS software (Version 20) by one-way analysis of variance (ANOVA). Duncan multiple range test was used to test the statistical significance at the $\alpha=0.05$ level.

\section{RESULTS AND DISCUSSION}

\section{REZULTATI I RASPRAVA}

\subsection{Mass loss and compression strength parallel} to the grain

3.1. Gubitak mase i čvrstoća na tlak paralelno s vlakancima

$P$. vitreus caused higher dry mass loss than $B$. subtilis UTB22. The average mass losses were less than $1 \%$ with $B$. subtilis UTB22 and $8.4 \%$ with $P$. vitreus (Table 1). Low mass loss after exposure to $B$. subtilis UTB22 might not be the sole consequence of the bacterial degradation; the leaching of extractives was also observed. Some previous works have reported smaller mass losses after colonization of the wood with the same isolate of $P$. vitreus for six weeks; for example, $4.7 \%$ for black poplar (Populus nigra) (Emaminasab et al., 2015), 2.1\% for the heartwood of Norway spruce (Lehringer et al., 2010), and $3.4 \%$ for the sapwood of Norway spruce and Douglas fir (Pseudotsuga menziesii) (Schwarze and Landmesser, 2000). Such a variation in the mass loss definitely implies that the fungal activity changes largely with the wood species, the wood block size, and incubation conditions. The compression strength parallel to the grain of the wood specimens was reduced by $16 \%$ and $7 \%$ after incubation with $B$. subtilis UTB22 and $P$. vitreus, respectively (Table 1). Other authors have also reported that a short period of wood incubation by $P$. vitreus caused a slight reduction in mechanical strength (Schwarze and Landmesser, 2000; Schwarze et al., 2006; Lehringer et al., 2010). However, the strength loss after incubation with $P$. vitreus can be significant for some wood species (Schwarze et al., 2006; Emaminasab et al., 2015). Schwarze et al. (2006) reported that the impact bending strength of Abies alba was reduced by about 31.5 $\%$ after incubation of $15 \mathrm{~cm}^{3}$ test blocks with EMPA 642 isolate of $P$. vitreus for 6 weeks. The unexpected higher loss of strength in bacterial-treated samples, despite their insignificant mass loss, can be attributed to the larger number of tracheids engaged in the decomposition of their pit membrane. This affects the continuity of the tracheid wall and results in a devaluation of some mechanical properties (Bucur, 1995).

\subsection{Wood degradation}

\subsection{Razgradnja drva}

Both microorganisms degraded the tracheid bordered pits and cross-field pits, which resulted in an opening of the aspirated pits (Figures 2 and 3). Pit degradation by $P$. vitreus was more severe than that by $B$. subtilis UTB22. The extent of the fungal degradation was not similar for all pits (Figures $3 a, b$, and e). The degradation for some pits was limited to the tori (Figure $3 \mathrm{~b}$, white arrow), but the membranes of some were completely degraded (Figure 3b, black arrow). Schwarze et al. (2006) also showed a similar pit degradation pattern after incubation of $P$. abies and $A$. alba with $P$. vitreus isolates of EMPA 642 and EMPA 643. In contrast to Schwarze and Landmesser (2000), Schwarze et al. (2006), and Schwarze et al. (2008) who reported a preferential degradation of pit membranes of Norway spruce tracheids at the initial stage of wood colonization with $P$. vitreus, SEM observations in the current study showed some signs of cell wall degradation (Figure 3a, white arrows). Lehringer et al. (2010) also found that some bore holes were formed in the tracheid cell walls even at early stages of $P$. vitreus colonization in Norway spruce. Therefore, in agreement with the report of Lehringer et al. (2010), a selective degradation of pit membranes with $P$. vitreus as claimed by Schwarze and Landmesser (2000) and Schwarze et al. $(2006,2008)$ is questionable, even at early stages of wood colonization. These contradictory results, however, may be due to different incubation conditions used by the authors, which implies that fungal activity is highly dependent upon the bioincising conditions. The degradation of pit membranes can be more selective by optimizing the incubation parameters (Lehringer, 2011). Degradation by B. subtilis UTB22 was confined to the pit tori (Figures 2c-d). A non-uniform

Table 1 Average mass loss, compression strength parallel to the grain, and air permeability of Loblolly pine heartwood blocks after incubation with Bacillus subtilis UTB22 and Physisporinus vitreus (Pers.: Fr.) P. Karsten isolate 136 for six weeks Tablica 1. Prosječni gubitak mase, čvrstoća na tlak paralelno s vlakancima i propusnost zraka kroz srž lobodijskog bora nakon šest tjedana inkubacije s Bacillus subtilis UTB22 i Physisporinus vitreus (Pers.: Fr.) P. Karsten izolat 136

\begin{tabular}{|c|c|c|c|c|}
\hline & \multirow{2}{*}{$\begin{array}{c}\text { Mass loss, } \% \\
\text { Gubitak mase, \% }\end{array}$} & \multirow{2}{*}{$\begin{array}{c}\text { Compression strength parallel } \\
\text { to the grain, MPa } \\
\text { Čvrstoća na tlak paralelno } s \\
\text { vlakancima, } \mathrm{MPa}\end{array}$} & \multicolumn{2}{|c|}{$\begin{array}{l}\text { Air permeability, } \mathbf{m}^{2} \cdot \mathbf{1 0}^{-15} \\
\text { Propusnost zraka, } \mathrm{m}^{2} \cdot 10^{-15}\end{array}$} \\
\hline & & & $\begin{array}{l}\text { Longitudinal } \\
\text { Uzdužno }\end{array}$ & $\begin{array}{l}\text { Tangential } \\
\text { Tangentno }\end{array}$ \\
\hline Control / Kontrolni uzorci & - & $32.17 \pm 1.2^{\mathrm{c}}$ & $6.70 \pm 0.6^{\mathrm{a}}$ & $2.8 \pm 0.3^{\mathrm{a}}$ \\
\hline Bacillus subtilis & $0.63 \pm 0.4^{\mathrm{a}}$ & $26.92 \pm 2.1^{\mathrm{a}}$ & $52.00 \pm 10.8^{c}$ & $16.4 \pm 2.3^{\mathrm{c}}$ \\
\hline Physisporinus vitreus & $8.42 \pm 1.9^{b}$ & $30.09 \pm 2.3^{b}$ & $15.00 \pm 1.6^{\mathrm{b}}$ & $6.4 \pm 0.7 \mathrm{c}^{\mathrm{b}}$ \\
\hline
\end{tabular}



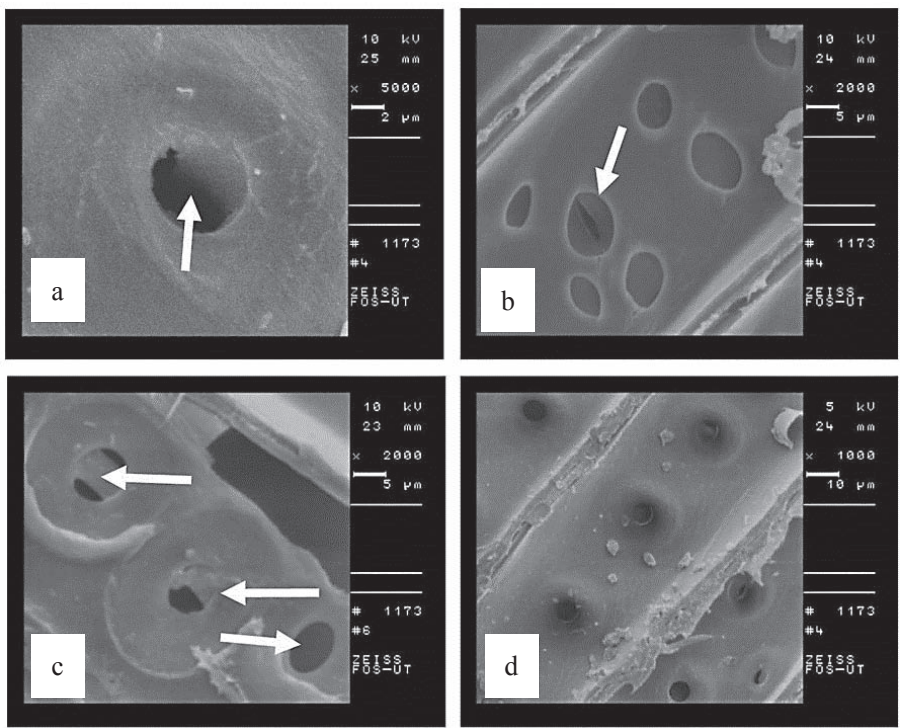

Figure 2 SEM images of wood specimens incubated by $B$. subtilis UTB22: a) partial degradation of tracheid bordered pit torus; b) an opened half-bordered pit aperture in the cross-field area; c) partial degradation of pit tori (leftward arrows) and complete degradation of torus (rightward arrow); d) pit degradation limited to tori

Slika 2. SEM mikrografije uzoraka drva zaraženih bakterijom B. subtilis UTB22: a) djelomična razgradnja traheide ograničena na torus jažice; b) poluotvorena jažica na poprečnom presjeku; c) djelomična razgradnja torusa jažice (lijeve strelice) i potpuna razgradnja torusa jažice (desna strelica); d) razgradnja jažice ograničena na torus
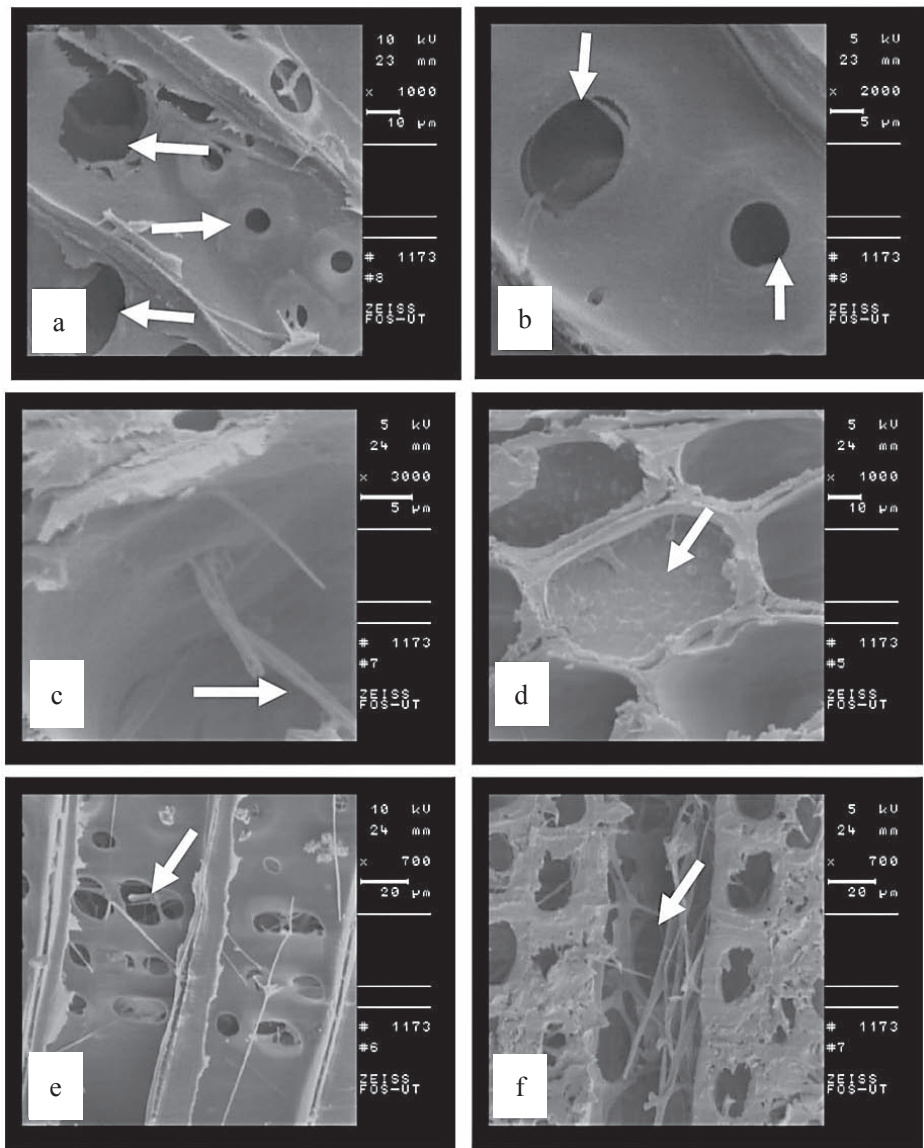

Figure 3 SEM images of wood specimens incubated by P. vitreus (Pers.: Fr.) P. Karsten isolate 136: a) totally degraded tracheid bordered pits together with cell wall degradation (leftward arrows) and unaffected bordered pit (rightward arrow); b) a completely digested pit (downward arrow) versus a pit with decomposed torus (upward arrow); c) passing of fungal hyphae through inter-tracheid pits; d) accumulation of fungal hyphae in a tracheid lumen; e) degradation of cross-field pits in the vicinity of hyphae; f) degradation of ray parenchyma cells

Slika 3. SEM mikrografije uzoraka drva zaraženih gljivom $P$. vitreus (Pers.: Fr.) P. Karsten izolat 136: a) potpuna razgradnja traheide na granici s jažicama s istodobnom razgradnjom stanične stijenke (lijeve strelice) i nepromijenjena ograđena jažica; b) potpuno razgrađena jažica (strelica prema dolje) u odnosu prema jažici s razgrađenim torusom (strelica prema gore); c) prolazak hifa gljive kroz jažicu između traheida; d) nakupine hifa gljive u lumenu traheide; e) razgradnja poprečnog presjeka jažice u blizini hifa; f) razgradnja parenhima u drvnim tracima 
penetration of fungal hyphae in the porous structure of wood (Figures 3a and c) was observed in the current study. A heterogeneous fungal colonization in timbers due to differences in the heartwood percentage, moisture content, and availability of nutrients is one of the main drawbacks of such biological incising methods on an industrial scale (Schwarze et al., 2006; Dale et al., 2019).

In agreement with previous reports (Schwarze and Landmesser, 2000; Schwarze et al., 2006; Lehringer et al., 2010; Fuhr et al., 2011), P. vitreus showed a much higher activity in earlywood than in latewood (see Figure $3 \mathrm{~d}$ for the fungal hyphae accumulation within the cell lumens), which is often attributed to the greater amount and more availability of nutrients in earlywood (Fuhr et al., 2011) as well as the higher resilience of latewood tracheids to decay. At the initial stage of wood colonization, degradation is more obvious in earlywood, but at the advanced stage of fungal activity, latewood was also attacked (Schwarze et al., 2008).

\subsection{Air permeability and micro-scale treatability}

3.3. Propusnost zraka i impregnacija na mikrorazini

Both $P$. vitreus and B. subtilis UTB22 were able to significantly enhance the permeability of Loblolly pine heartwood (Table 1), which was increased by around $56 \%$ in the tangential direction and $124 \%$ in the longitudinal direction after fungal exposure. The improvement was more remarkable when the specimens were exposed to B. subtilis UTB22 (485\% for tangential permeability and $676 \%$ for longitudinal permeability). Several studies have also shown that different isolates of $P$. vitreus can significantly improve wood permeability, even after a short period of colonization (Schwarze and Landmesser, 2000; Schwarze et al., 2006; Lehringer et al., 2010; Fuhr et al., 2011; Emaminasab et al., 2015, 2016); however, the changes in permeability vary with the wood species, the fungal isolate, and incubation conditions (Schwarze et al., 2006). The improvement in permeability is mostly attributable to the degradation of the pit membranes (Schwarze et al., 2006; Schwarze and Schubert, 2011; Fuhr et al., 2011). It is believed that the secretion of pectinase enzyme by $B$. subtilis plays an important role in improving wood permeability through the decomposition of pectin compounds and hemicellulose of the pit membrane (Yildiz et al., 2012). Possible reasons for the lower improvement in permeability by $P$. vitreus compared to $B$. subtilis UTB22 are the heterogeneous fungal activity, accumulation of fungal hyphae, and degradation products within the cell lumens (Figure $3 \mathrm{~d}$ ), which may block the fluid flow paths (Emaminasab et al., 2015).

Micro-scale treatability studies under a fluorescence microscope showed that the treatability of the tracheid cells increased after incubation by both microorganisms (Figure 4). The present results clearly demonstrate the higher bioincising efficiency of $B$. subtilis UTB22 compared to $P$. vitreus (Pers.: Fr.) P. Karsten isolate 136. While most tracheid lumina were filled with the impregnating solution after bacterial exposure (Figures 4c, e), many of the lumina remained empty in the wood specimens bioincised by $P$. vitreus (Figures $4 b, d)$.

A non-uniform penetration of the solution into the specimens exposed to P. vitreus (Figure 4b) may be

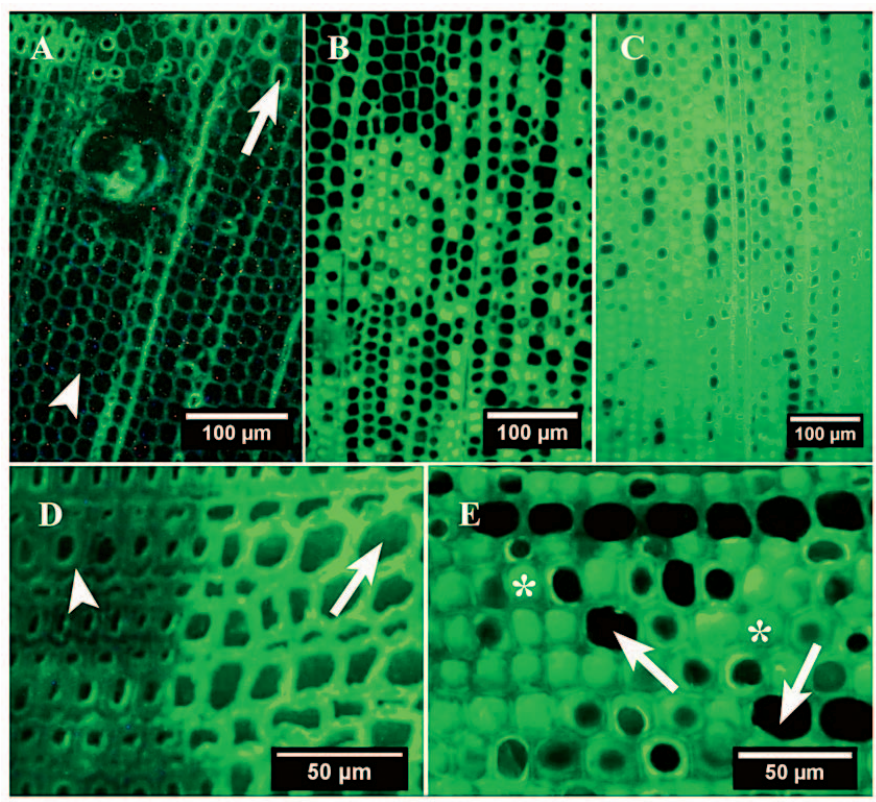

Figure 4 Microscopic treatability of wood samples using fluorescent dye-containing water: A) control, B) and D): fungal treated, C) and E) bacterial treated samples; the green color shows the presence of fluorescence solution; arrowheads, arrows, and asterisks, respectively, show untreated tracheids, tracheids with treated cell walls, and tracheids in which both cell wall and lumen are filled with liquid

Slika 4. Mikroskopska obrada uzoraka drva uz pomoć fluorescentnog bojila otopljenoga u vodi: A) kontrolni uzorak, B) i D) uzorci zaraženi gljivom, C) i E) uzorci zaraženi bakterijom; zelena boja potvrđuje prisutnost fluorescentne otopine; vrhovi strelica, strelice i zvjezdice pokazuju neimpregnirane traheide, traheide s impregniranim staničnim stijenkama i traheide s impregniranim staničnim stijenkama i lumenima 

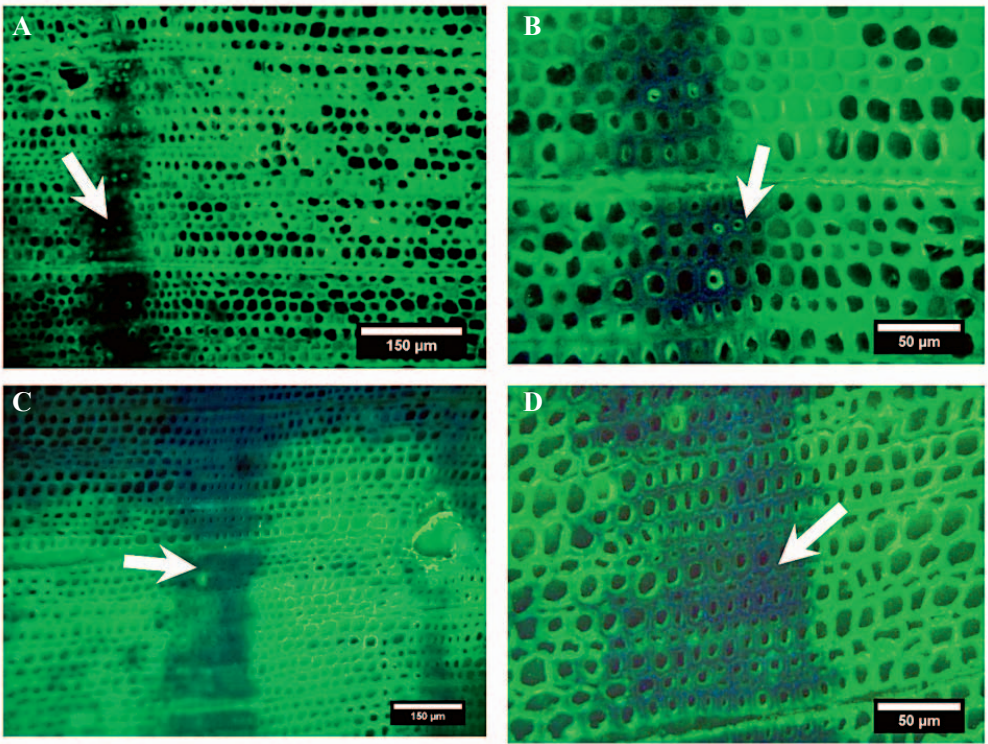

Figure 5 The treatability of earlywood vs. latewood of wood specimens; a) and b) incubated with B. subtilis UTB22; c) and d) incubated with $P$. vitreus (Pers.: Fr.) P. Karsten isolate 136. Arrows show untreated latewood

Slika 5. Impregnacija ranog drva u usporedbi s kasnim: a) i b) uzorci zaraženi bakterijom B. subtilis UTB22; c) i d) uzorci zaraženi gljivom P. vitreus (Pers.: Fr.) P. Karsten izolat 136.; strelice pokazuju neimpregnirano kasno drvo

because of the heterogeneous opening of the aspirated bordered pits by the fungus. Schwarze et al. (2006) visually inspected the uptake of bluish dye Neolan Glaucin E-A by Norway spruce and silver fir (Abies $a l b a)$ wood blocks incubated with two isolates of $P$. vitreus (EMPA 642 and EMPA 643), and found that the uptake within P. abies was less homogeneous. Lehringer et al. (2009a) also reported that the uptake and penetration depth of aqueous modification substances after vacuum impregnation of the bioincised wood were highly variable due to the heterogeneous colonization of the wood by $P$. vitreus.

After bioincising, earlywood showed better treatability than latewood (Figure 5). Only a few latewood cells were treated even after the fungal or bacterial incubation, which indicates the weaker ability of the microorganisms to degrade latewood cells. Therefore, this treatability enhancing strategy may be less successful in improving the treatability of softwoods with high latewood percentage, like the Pinaceae family.

\section{CONCLUSIONS}

\section{ZAKLJUČAK}

The present work comparatively studied the degradation pattern, permeability, and micro-scale treatability of Loblolly pine heartwood after incubation with two bioincising microorganisms (white-rot fungus Physisporinus vitreus (Pers.: Fr.) P. Karsten isolate 136 and bacterium Bacillus subtilis UTB22). Both microorganisms improved treatability significantly, mainly because of degradation of the pit membranes. However, a higher treatability with more uniform impregnation of the wood cells was obtained with $B$. subtilis UTB22 despite a higher mass loss with $P$. vitreus. SEM observations showed that the lower treatability enhancing efficiency of the fungus was possibly due to the heterogeneous pit degradation and blockage of the tracheid lumens with the fungal hyphae. Earlywood was more treatable than latewood after bioincising because of the higher degradation of the former.

It can be concluded that degradation by $B$. subtilis UTB22 was more selective than that by $P$. vitreus (Pers.: Fr.) P. Karsten isolate 136. Degradation by the bacterium was mainly confined to the tori of the pits, whereas some pits were completely degraded by the fungus and the cell walls were also attacked. Based on the current results, a heterogeneous impregnation of the bioincised wood cells can also be an important challenge for scaling up the bio-incising of wood with $P$. vitreus to an industrial scale.

\section{REFERENCES}

5. LITERATURA

1. Bari, E.; Taghiyari, H. R.; Schmidt, O.; Ghorbani, A.; Aghababaei, H., 2015: Effects of nano-clay on biological resistance of wood-plastic composite against five wooddeteriorating fungi. Maderas. Ciencia y Tecnologia, 17: 205-212.

http://dx.doi.org/10.4067/S0718-221X2015005000020.

2. Bucur, V., 1995: Acoustics of wood. CRC Press. Boca Raton, New York, London, Tokyo.

3. Dale, A.; Morris, P. I.; Uzunovic, A.; Symons, P.; Stirling, R., 2019: Biological incising of lodgepole pine and white spruce lumber with Dichomitus squalens. European Journal of Wood and Wood Products, 77: 1161-1176. https://doi.org/10.1007/s00107-019-01471-2.

4. Daniel, G., 2003: Microview of wood under Degradation by Bacteria and Fungi, Wood Deterioration and Preservation. American Chemical Society, pp. 34-72. https://doi.org/10.1021/bk-2003-0845.ch004.

5. Emaminasab, M.; Tarmian, A.; Pourtahmasi, K., 2015: Permeability of Poplar normal wood and tension wood bioincised by Physisporinus vitreus and Xylaria lon- 
gipes. International Biodeterioration \& Biodegradation, 105: $178-184$.

https://doi.org/10.1016/j.ibiod.2015.09.003.

6. Emaminasab, M.; Tarmian, A.; Pourtahmasi, K.; Avramidis, S., 2016: Improving the permeability of Douglasfir (Pseudotsuga menziesii) containing compression wood by Physisporinus vitreus and Xylaria longipes. International Wood Products Journal, 7: 110-115. https://doi.org/10.1080/20426445.2016.1155788.

7. Evans, P. D., 2016: The effects of incising on the checking of wood: A review. International Wood Products Journal, 7 (1): 12-25. https://doi.org/10.1080/20426445.2015.1112936.

8. Fuhr, M. J.; Schubert, M.; Schwarze, F. W. M. R.; Herrmann, H. J., 2011: Modelling the hyphal growth of the wood-decay fungus Physisporinus vitreus. Fungal Biology, 115: 919-932.

9. Greaves, H., 1970: The effect of some wood-inhabiting bacteria on the permeability characteristics and microscopic features of Eucalyptus regnans and Pinus radiata sapwood and heartwood. Holzforschung, 24: 6-14. https://doi.org/10.1515/hfsg.1970.24.1.6.

10. Hansmann, A.; Gindl, W.; Wimmer, R.; Teischinger, A., 2002: Permeability of wood - A review. Wood Research, 47:1-16.

11. Johnson, B. R., 1979: Permeability changes induced in three western conifers by selective bacterial inoculation. Wood and Fiber Science, 11: 10-21.

12. Lehringer, C.; Hillebrand, K.; Richter, K.; Arnold, M.; Schwarze, F. W. M. R.; Militz, H., 2010: Anatomy of bioincised Norway spruce wood. International Biodeterioration \& Biodegradation, 64: 346-355. https://doi.org/10.1016/j.ibiod.2010.03.005.

13. Lehringer, C.; Arnold, M.; Richter, K.; Schubert, M.; Schwarze, F. W. M. R.; Militz, H., 2009a: Bioincised wood as substrate for surface modification. In: Proceedings of The fourth European conference on wood modification. Stockholm, pp. 197-200.

14. Lehringer, C.; Richter, K.; Schwarze, F. W. M. R.; Militz, H., 2009b: A review on promising approaches for liquid permeability improvement in softwoods. Wood and Fiber Science, 41: 373-385.

15. Lehringer, C.; Saake, B.; Živković, V.; Richter, K.; Militz, H., 2011: Effect of Physisporinus vitreus on wood properties of Norway spruce. Part 2: Aspects of microtensile strength and chemical changes. Holzforschung, 65(5): 721-727. https://doi.org/10.1515/hf.2011.090.

16. Mai, C.; Kües, U.; Militz, H., 2004: Biotechnology in the wood industry. Applied Microbiology and Biotechnology, 63(5): 477-494. https://doi.org/10.1007/s00253-003-1411-7.

17. Morrell, J. J.; Morris, P. I., 2002: Methods for improving preservative penetration into wood: A review. In: Proceedings of $33^{\text {nd }}$ annual meeting of the international research group on wood protection, IRG/WP 02-40227. Cardiff.

18. Omidvar, A.; Schneider, M. H., 2004: Evaluation of fluid distribution in pressure treated wood in different flow directions. In: Proceedings of $35^{\text {nd }}$ annual meeting of the international research group on wood protection, IRG/ WP 04-40281. Ljubljana.

19. Pánek, M.; Reinprecht, L., 2008: Bio-treatment of spruce wood for improving of its permeability and soaking. Part 1: Direct treatment with the bacterium Bacillus Subtilis. Wood Research, 53: 1-12.
20. Pánek, M.; Reinprecht, L., 2011: Bacillus subtilis for improving spruce wood impregnability. BioResources, 6: 2912-2931.

21. Schmidt, O.; Schmitt, U.; Moreth, U.; Potsch, T., 1997: Wood decay by the white-rotting basidiomycete Physisporinus vitreus from a cooling tower. Holzforschung, 51:193-200. https://doi.org/10.1515/hfsg.1997.51.3.193.

22. Schwarze, F. W. M. R.; Landmesser, H., 2000: Preferential degradation of pit membranes within tracheids by the Basidiomycete Physisporinus vitreus. Holzforschung, 54: 461-462. https://doi.org/10.1515/HF.2000.077.

23. Schwarze, F. W. M. R.; Landmesser, H.; Zgraggen, B.; Heeb, M., 2006: Permeability changes in heartwood of Picea abies and Abies alba induced by incubation with Physisporinus vitreus. Holzforschung, 60: 450-454. https://doi.org/10.1515/HF.2006.071.

24. Schwarze, F. W. M. R.; Schubert, M., 2011: Physisporinus vitreus: a versatile white rot fungus for engineering value-added wood products. Applied Microbiology and Biotechnology, 92: 431-440. https://doi.org/10.1007/s00253-011-3539-1.

25. Siau, J. F., 1984: Transport processes in wood. Springer, Heidelberg, pp. 248.

26. Tarmian, A.; Zahedi Tajrishi, I.; Oladi, R.; Efhamisisi, D., 2020: Treatability of wood for pressure treatment processes: a literature review. European Journal of Wood and Wood Products, 78: 635-660. https://doi.org/10.1007/s00107-020-01541-w.

27. Thaler, N.; Lesar, B.; Kariž, M.; Humar, M., 2012: Bioincising of Norway spruce wood using wood inhabiting fungi. International Biodeterioration \& Biodegradation, 68: 51-55. https://doi.org/10.1016/j.ibiod.2011.11.014.

28. Volkmer, T.; Landmesser, H.; Genoud, A.; Schwarze, F. W. M. R., 2010: Penetration of 3-iodo-2-propynyl butylcarbamate (IPBC) in coniferous wood pre-treated with Physisporinus vitreus. Journal of Coatings Technology and Research, 7:721-726.

https://doi.org/10.1007/s11998-010-9259-0.

29. Yildiz, S.; Canakci, S.; Yildiz, U. C.; Ozgenc, O.; Tomak, E. D., 2012: Improving of the impregnability of refractory spruce wood by Bacillus licheniformis pretreatment. BioResources, 7: 565-577.

30. ***DIN 52185, 1976: Testing of wood - compression test parallel to grain. Beuth Verlag $\mathrm{GmbH}$, Berlin.

31. ***EN 350, 2016: Durability of wood and wood-based products-testing and classification of the durability to biological agents of wood and wood-based materials. European Committee for Standardisation (CEN). Brussels, Belgium.

32. $* * * E N 113,2004$ : Wood preservatives - Test method for determining the protective effectiveness against wood destroying basidiomycetes - Determination of toxic values. European Committee for Standardization (CEN). Brussels, Belgium.

\section{Corresponding address:}

\section{ASGHAR TARMIAN}

University of Tehran

Faculty of Natural Resources

Department of Wood and Paper Science \& Technology Karaj, IRAN

e-mail: tarmian@ut.ac.ir 